\title{
Competency Profile in Genetics for Physicians in Brazil: A Proposal of the Brazilian Society of Medical Genetics and Genomics
}

\author{
Perfil de Competência em Genética para \\ Médicos do Brasil: uma Proposta da \\ Sociedade Brasileira de Genética Médica e \\ Genômica
}

\author{
Débora Gusmão Melo ${ }^{I}$ \\ André Anjos da Silva ${ }^{I I}$ \\ Antonette Souto El Husny III \\ Victor Evangelista de Faria Ferraz ${ }^{I V}$
}

\section{PALAVRAS-CHAVE}

- Competência Profissional.

- Competência Clínica.

- Genética Médica.

- Educação Médica.

- Educação Baseada em Competências.

- Brasil.

Educação em genética é fundamental para o entendimento dos aspectos biológicos do binômio saúde-doença. Além disso, com a mudança do perfil epidemiológico, as doenças com determinantes genéticos tornaram-se mais relevantes como problema de saúde pública. Assim, manejar estas doenças, tanto em pacientes como em suas famílias, de forma ética, diligente e considerando a lógica e as políticas do Sistema Único de Saúde (SUS), passa a ser competência desejável para todos os médicos, impactando sua formação na graduação. Entendendo esta questão como absolutamente relevante, a Sociedade Brasileira de Genética Médica e Genômica (SBGM) definiu as competências desejáveis em genética para os médicos do Brasil, articuladas às politicas públicas relacionadas à área existentes no País. Este artigo é um ensaio teórico que objetiva contextualizar e apresentar o perfil de competência em genética para médicos proposto pela SBGM. O perfil de competência, apresentado e discutido neste ensaio, foi estruturado com base em quatro competências essenciais: (a) reconhecer a necessidade de educação continuada, examinando regularmente a sua própria competência clínica; (b) identificar indivíduos que apresentem ou possam desenvolver uma doença genética e saber como e quando encaminhá-los para aconselhamento genético; (c) manejar pacientes com doenças genéticas e/ou defeitos congênitos no âmbito da sua atuação profissional; (d) promover e estimular práticas clínicas e de educação em saúde, objetivando a prevenção de doenças genéticas e defeitos congênitos. Conhecimentos, habilidades e atitudes necessários para alcançar essas quatro competências foram elencados. Dessa forma, é apresentado um referencial teórico, baseado em competências, para apoiar o ensino da genética durante a graduação em Medicina. Defende-se a adoção deste perfil de competência mínimo em genética em todas as escolas médicas brasileiras com a finalidade de formar um médico mais adequado às atuais demandas do SUS. Adicionalmente, esse perfil de competência pode subsidiar ações de educação profissional permanente na área da genética, de forma a capacitar o recurso humano do SUS em relação às doenças genéticas e aos defeitos congênitos.

IV Universidade de São Paulo, Ribeirão Preto, São Paulo, Brasil. 


\section{KEY-WORDS}

- Professional Competency.

- Clinical Competency.

- Medical Genetics.

- Medical Education.

- Competency-Based Education.

- Brazil

Recebido em: 24/5/19

Aceito em: 1/7/19

Training in genetics is fundamental to understanding the biological aspects of the health-disease binomial. Moreover, with the change in the epidemiological profile, genetically determined disorders have become more relevant as a public health concern. Thus, managing these disorders in an ethical and diligent manner, both in patients and in their families, and considering the logic and policies of the Brazilian Unified Health System (SUS), has become a desirable competency for all physicians, impacting on their undergraduate training. Viewing this issue as relevant, the Brazilian Society of Medical Genetics and Genomics (SBGM) defined the desirable competencies in genetics for Brazilian physicians, tied to the public policies related to medical genetics in Brazil. This paper is a theoretical essay that aims to contextualize and present the competency profile in Genetics for physicians proposed by the SBGM. The proficiency profile, presented and discussed in this essay, was structured based on four essential competencies: (1) to recognise the necessity for continuing education, regularly examining one's own clinical competency, identifying learning gaps and the advances of genetics and of genomics over time; (2) to identify individuals that present or can develop a genetic disorder and know how and when to refer the patient to a specialist in medical genetics; (3) to manage patients with previously diagnosed genetic disorders and/or birth defects, employing established clinical guidelines in the scope of their professional role; and (4) to promote and stimulate clinical and education practices aimed at preventing genetic disorders and birth defects. The knowledge, skills and attitudes required for attaining these four competencies were identified. Therefore, a competency-based theoretical reference is presented to support the teaching of genetics during medical training. It is proposed that this essential competency profile in genetics should be adopted in all Brazilian medical schools with the purpose of training physicians better prepared for the current demands of the SUS. Furthermore, this competency profile can support continuing professional education actions in the area of Genetics, in order to qualify SUS staff in relation to genetic disorders and birth defects.

\section{INTRODUCTION}

Education in genetics is fundamental for understanding of the biological aspects of the health-disease binomial ${ }^{1}$. Furthermore, the change in the epidemiological profile has rendered genetically determined disorders increasingly relevant as a public health concern ${ }^{2}$. Thus, managing these disorders in an ethical and diligent manner, both in patients and in their families, and considering the logic and policies of the Brazilian Unified Health System (SUS), has become a desirable competency for all physicians, impacting on their undergraduate training ${ }^{3,4}$.

This was recognised in the latest version of the National Curriculum Guidelines for Undergraduate Medicine Courses, published in 2014, which explicitly determined how as a competency in its article 12: "IV - Promotion of Diagnostic Investigation: a) proposition and explanation, to the person under care or responsible individual, about the diagnostic investigation to broaden, confirm or remove diagnostic hypotheses, in- cluding recommendations to perform genetic counselling" (emphasis added) ${ }^{5}$.

Viewing this issue as relevant, the Brazilian Society of Medical Genetics and Genomics (SBGM) defined the desirable competencies in genetics for Brazilian physicians, tied to the public policies related to medical genetics in Brazil. This paper is a theoretical essay that aims to contextualize and present the competency profile in Genetics for physicians proposed by the SBGM. Therefore, a competency-based theoretical reference is presented to support the teaching of genetics in Brazilian medical schools.

\section{HEALTH CARE IN THE AREA OF GENETICS IN BRAZIL}

Medical genetics deals with individually rare diseases, but when considered collectively have an estimated prevalence of 31.5 to 73.0 per one thousand individuals ${ }^{1}$. Genetic disorders are the result of chromosomal or genic alterations, that modify the production, structure and/or function of proteins, 
culminating in metabolic dysfunctions, morphological and/or functional abnormalities ${ }^{1}$. Genetic disorders may or may not be hereditary, given that some genetic disorders are not inherited and occur due to "new mutations". Genetic disorders can be congenital, indicating alteration during the embryofoetal period, or can be late-onset disorders, such as several progressive neurogenetic diseases and cancers ${ }^{1,6}$.

The impact of genetic disorders can be observed in the different age groups. Chromosomal abnormalities are present in approximately $50 \%$ of all foetal losses in the first three months ${ }^{6}$. In general, $5 \%$ of newborns present some serious birth defect, totally or partially determined by genetic factors $^{7,8}$. In Brazil, the prevalence of serious birth defects among newborn babies has been estimated at 57.2 per thousand ${ }^{9,10}$. Sensory deficiencies, such as deafness and blindness, as well as physical and mental deficiencies, are frequently part of the phenotype of genetic syndromes and it is estimated that more than $50 \%$ of the cases of isolated congenital deafness are caused by monogenic mutations. In adults, approximately $5 \%$ to $10 \%$ of common cancers, such as breast and intestinal, have a strong hereditary component $t^{6}$.

Genetic disorders are responsible for a large proportion of paediatric hospital admissions, mental deficiencies, neurodegenerative diseases and infertility, reinforcing the considerable effect that they have on health and quality of life $^{11}$. Individuals with genetic disorders also frequently require special care in the areas of health and education, and supervision to perform basic and instrumental activities of daily life. The repercussion of genetic disorders on family life, therefore, tends to be significant and can lead to loss of earnings for the main carer of the patient, thus also impacting on the family budget ${ }^{12}$.

The epidemiological impact of birth defects and genetic disorders starts to be of particular notice when the infant mortality rate reaches rates of less than 20 per thousand ${ }^{13}$. This has been the case in all regions of Brazil since 2005, when genetic disorders, addressed in Chapter XVII of the International Classification of Diseases (Congenital malformations, deformations and chromosomal abnormalities"), became the second most common cause of infant mortality ${ }^{14}$.

In Brazil, medical genetic services began to develop in the 1960s and 1970s, usually connected to graduate courses in Human and/or Medical Genetics. During the 1970s and 1980s, services with greater care capacity were constructed, connected to public universities ${ }^{15}$. A survey conducted in 2001 identified 64 medical genetics care services in Brazil: 37 (58\%) in the Southeast Region (75.7\% in São Paulo State), 17 (26\%) in the South Region, 7 (11\%) in the Northeast Region and 3 $(5 \%)$ in the Mid-West. At the time no such service was located in the North Region. The types of service offered were very diverse, some being very extensive in scope (clinical services, laboratorial services and research), while other places offered only genetic counselling ${ }^{7}$.

The number of health professionals involved in medical genetic care in Brazil is insufficient to meet the demand and it is estimated that most patients and families with genetic disorders do not receive the adequate care ${ }^{3,4}$. There are 11 residency programs in Medical Genetics in Brazil, which offer 23 new placements for medical residents per year'. In 2014, the Federal Medical Council (CFM) officially recognised 241 medical specialists in genetics ${ }^{16}$, most of whom are under the SBGM. The geographic distribution of these professionals is related to the populational density and human development index of the regions, and, especially in the poorest and least populated areas there is a greater lack of such professionals ${ }^{4}$.

The scarcity of specialized human resources, without doubt, represents an impediment against the inclusion of clinical genetic care in the SUS $2,3,4,10$. This lack of specialists is aggravated by the incipient training in genetics of health professionals who are not specialists in the area ${ }^{4,17,18,19}$.

\section{PUBLIC HEALTH POLICIES RELATED TO GENETICS IN BRAZIL}

The first national public policy initiative related to medical genetics in Brazil was established in the National Neonatal Triage Program (PNTN) in $2001^{20}$. Before then, there had been some state laws relative to neonatal triage of congenital hypothyroidism and phenylketonuria, such as, for example, São Paulo State Law 3.914/198321 and Paraná State Law 867/198722, but no policy that covered all Brazilian newborns. Since 2001, all the states have participated in the PNTN, performed in the SUS-accredited Reference Neonatal Triage Services, which should offer a structure for diagnosis, active search, treatment and monitoring of identified patients ${ }^{23}$. The objective of the PNTN is to identify among apparently healthy newborns those who have or who will probably develop a disorder and could benefit from early detection and intervention ${ }^{24,25}$. Neonatal triage in Brazil was implemented in phases and, since 2014, all Brazilian states have performed tracing for phenylketonuria, congenital hypothyroidism, hemoglobinopathies, cystic fibrosis, biotinidase deficiency and congenital adrenal hyperplasia ${ }^{26}$.

A second public policy that touches on health care in the field of genetics is the National Health Policy for the Disabled, established in 2002 with the purpose of including people with disability throughout the SUS service network, promoting diagnosis, treatment and rehabilitation ${ }^{27}$. In the manuals and guidelines that followed the promulgation of this policy, ge- 
netic disorders and birth defects were identified as the common causes of disabilities, stimulating patient to access the services of genetic clinic and genetic counselling 28,29 . Ten years after the publication of the National Health Policy for the Disabled, recognising the complexity involved in health care for disabled people and perceiving the need to broaden, quality and diversity the assistance strategies for these people, the Ministry of Health established the Care Network for the Disabled under the SUS $^{30}$. The idea of networking is to enhance the connections between the different services, thus ensuring comprehensive care. Nevertheless, in practice one can still observe a persistent disconnect between the different components of this network, which are often limited to providing care for disabled people in an isolated manner ${ }^{31}$ and can fail to consider the possible genetic dimension involved in the aetiology of the disability.

Furthermore, since the early 2000s, the Ministry of Health has published clinical protocols and treatment guidelines related to genetic disorders, both rare ${ }^{32-35}$ and not ${ }^{36,37}$. Governmental actions are also important, as foreseen and supported by national laws in relation to the prevention of birth defects, which include the requirement to fortify wheat and corn flours with folic acid as from $2004^{38}$ and the fight against congenital rubella through the National Immunization Program ${ }^{8,39,40}$. An important epidemiological surveillance measure in the area was to include a specific field in the live birth declaration to record birth defects, which, despite underreporting of the instrument, has allowed monitoring of the main anomalies suffered in the country ${ }^{8,39,41,42}$. However, all these measures are disconnected and there was no single public policy specifically directed at care in the area of medical genetics.

The formal discussion about the establishment of a specific public health policy for assistance in genetics in Brazil began in 2004 and resulted in the publication of the National Policy for Comprehensive Care in Clinical Genetics in the SUS, in $2009^{43}$. More recently, the Ministry of Health has directed efforts at implementing the National Policy of Comprehensive Care for People with Rare Diseases ${ }^{44}$ and, as $80 \%$ of rare diseases are also genetic disorders, this policy is seen as an opportunity to insert genetics into the SUS ${ }^{4,18}$. Approved in 2014, this policy classifies diseases according to their origin as genetic or non-genetic. Therefore, two strands were categorized, the first of which shelters three groups of genetic disorders: (a) congenital or late-onset anomalies, (b) mental disability and (3) inborn errors of metabolism; and the second strand covers rare diseases of a non-genetic nature ${ }^{44}$.

According to the guidelines of the National Policy of Comprehensive Care for People with Rare Diseases, this care should be structured according to the care model, producing health in a systemic manner, centred around the recognition and dynamic and ongoing care of the users' needs. The SUS shall thus ensure comprehensive and coordinated care within the health care network. This policy foresees specific functions for Primary Health Care (PHC) and Specialized Outpatient and Hospital Care. PHC should be responsible for the coordination of the health care and longitudinal follow-up of the population registered under its responsibility, as well as being the main point of access and gateway into the SUS network. This policy establishes nine specific attributes of the role of PHC, including: early diagnosis actions by means of identifying signs and symptoms; mapping people with, or at risk of developing, genetic disorders and/or birth defects for regulated referral; clinical follow-up after diagnosis and genetic counselling; promotion of education in health with the aim of prevention and expanding autonomy; continuous and longitudinal assessment of the patient and his family; and home care in specific cases ${ }^{44}$.

As the first to have contact with users, the PHC professionals play a key role in recognizing individuals with, or at risk of developing, genetic disorder or birth defect, in making the correct referral and giving the correct guidance in these sitation $^{17,18,19,45}$. In this regard, professionals who are not specialists in genetics, above all those who work in PHC, must be progressively more clinically competent in relation to medical genetics.

\section{PROFILE OF GENETIC COMPETENCY FOR PHYSICIANS}

The concept of "competency" has taken different meanings over time, in terms of both education and work ${ }^{46,47}$. In Brazil, the Law of Base Directives of Education is based on references to the genetic epistemology of Jean Piaget and the linguist Noam Chomsky, understanding that competencies are network-structured mental operations that, when engaged, allow the incorporation of new knowledge and their signified integration into that network. With these guidelines, pedagogical practice is tied to the construction, appropriation and engagement of significant pieces of understanding, and not restricted to the transmission of knowledge ${ }^{48}$.

In the scope of work, the term "competency" has been associated to a variety of attributes, such as abilities, skills and qualifications, which would be adequate and expected in the performance of certain professional activities ${ }^{49}$. From a highly reductionist point of view, on can understand professional competency as the ability to resolve a problem in a given situation based on results. Drilling deeper into the concept, pro- 
fessional competency can be understood as an identifiable and assessable set of knowledges, attitudes, values and abilities, which are interrelated and support satisfactory performances in real work situations, according to standards used in the occupational area ${ }^{50}$.

The incorporation of the concept of competency in the scope of work has interfered in education, modifying teaching, which is no longer centred around disciplinary knowledge to be defined by the production of verifiable competencies in specific situations and tasks ${ }^{47}$. These competencies should be defined with reference to situations which the students must be capable of understanding and mastering. Only after these definitions are established are the contents of the training selected ${ }^{47}$. Perrenoud et al..$^{51}$ point out the fact that the recognition of a competency does not only involve the identification of situations to be controlled, problems to be resolved or decisions to be made, but also the explanation of knowledges, abilities, mindsets and necessary ethical orientations ${ }^{51}$. For these authors, "competency" can be considered like a skill to tackle a set of analogous situations, engaging in a correct, quick, pertinent and creative manner multiple cognitive resources: knowledge, abilities, micro-competencies, information, values, attitudes, schemes of perception, evaluation and reasoning ${ }^{51}$.

Several elements are identified as part of the theoretical construct of "competency". Regardless of the theoretical reference used, "knowledge", "skills" and "attitudes" are recognised as structuring elements of "competency"52,53. Knowledge can be understood as the act of effect of abstracting and idea or notion of something, that is, it is the theoretical and practical knowing that incorporates concepts, principles and processes of the natural sciences, of mathematics and of human sciences. Skills are the result of learning consolidated in the form of habitus, thus representing a knowing-how-to-do ${ }^{54}$. The concepts of "skill" and "attitude" differ inasmuch as the former is associated to problem solving, integrating abstract reasoning, memory and cognitive processes, whereas "attitude" is based on personal characteristics and values associated to judgment ${ }^{52}$.

Particularly in the field of medicine, Epstein and Hundert ${ }^{55}$ understand "competency" as the habitual and judicious use of communication skills, knowledge, technical skills, clinical reasoning, emotions, values and reflections on the practice, allied to the ability to keep oneself up-to-date, for the benefit of the individual or the community that is being served. Arguments are also made that competency should have an effect on an individual's ability to care for another, putting into practice knowledge, skills and values to prevent and solve health problems $^{56}$.
In Brazil, the National Curriculum Guidelines for Undergraduate Medicine Courses detail the understanding of "competency" as the ability to engage knowledge, skills and attitudes, with the use of the available resources, expressed in initiatives and actions that convey performances capable of pertinently, opportunely and successfully tackling the challenges faced in professional practice, in different work settings in health, resulting in a medical practice of excellence, primarily in scenarios of the SUS 5 .

Currently the construction of curricula in health professions, both in undergraduate training and in specialization programs, such as medical residency, have been based on expected competencies, drawing from them the training and evaluation processes necessary for their implementation ${ }^{56}$. The "competencies matrix" is the base element for building a competency-based curriculum, expressing collective consensuses regarding the indispensable content that every student should know by their graduation, identifying the elements involved in the constitution of the competency. Therefore, ideally this matrix should be collectively constructed, based on the in-thefield experience of professionals with recognised excellence, educators and other professionals related to the theme ${ }^{57}$.

Since the 1990s many international groups have worked toward establishing a profile or matrix of minimum competencies in genetics for health professionals and, in particular, physicians ${ }^{58-62}$. The Human Genome Project, which formally began in 1990 and ended in 2003, drove the need to recognise medical genetics as an area of interest positioned among the priorities of medical education. There was the recognition that health professionals were experiencing the advent of a revolutionary change, based on the incorporation of genetics into health care, and that all medical specialities would be affected $^{63,64}$. With the rapid advance of medical genetics and the small number of specialists in the area, the importance of all physicians learning and applying basic and clinical concepts of genetics has been acknowledged. In 2004, the Association of American Medical Colleges outlines the key competencies for genetics that all Medicine students and resident physicians in the USA should dominate by the end of their training ${ }^{65}$.

In 2007, the National Coalition for Health Professional Education in Genetics (NCHPEG), a not-for-profit organization with the mission of promoting the training of health professionals and access to information about advances in human genetics, established the "Essential competencies in genetics for health professionals"66. The NCHPEG considers it fundamental that a health professional is able to: (a) recognise clinical situations which involve genetics or in which the knowledge of genetics helps in handling the situation; (b) un- 
derstand that genetic information can have significant medical, social and psychological consequences for the patient and family; (c) know when and how to refer a patient to a health professional specialist in genetics. For these three objectives to be attained, the NCHPEG organised the essential competencies in genetics into knowledge, skills and attitudes, general to all health professionals ${ }^{66}$.

In 2008, the European Society of Human Genetics adopted a minimum profile of competencies in genetics, specific to general practitioners and nurses; and also another profile, specific to specialist physicians and nurses in areas other than genetics, as well as to dentists ${ }^{67}$. Undoubtedly, the integration of genetics into health care requires basic knowledge of common genetic disorders and patterns of hereditariness, prevention measures, genetic tests and treatment innovations. But it also implies skills related to the ability to collect, record and interpret a family history and to non-directive and non-coercive communication, as well as attitudes related to interdisciplinary teamwork, confidentiality of information ${ }^{68-72}$.

International experiences in the scope of education show that much of the content in genetics continues to be discussed in the first two years of the medical course, which hinders the application of theoretical knowledge in clinical practice $e^{73,74,75}$. Pedagogical experiences in which genetics is addressed longitudinally, over the course of the entire medical course, integrated with other subjects, have been recommended ${ }^{75,76,77}$.

On a national level, a survey conducted at medical schools between 2000 and 2003 showed that, despite being well established, the teaching of genetics was extremely varied and required definition in terms of the clinical objectives $^{78}$. Experiences have been reported in clinical internships at specialist associations for supporting disabled people ${ }^{79}$ and in systematized training for resident family and community physicians $^{45}$.

\section{PRESENTATION OF A PROFILE OF GENETIC COMPETENCY FOR BRAZILIAN PHYSICIANS}

A working group, composed of five genetic physicians, all university professors, began the discussion about a specific profile in genetic competencies for physicians in Brazil, taking as a starting point a previous, broader document developed by the SBGM and aimed at health professionals in general ${ }^{4}$. Following rounds of debate by electronic correspondence a proposed matrix of specific competencies in genetics for physicians was constructed, which was published for consultation among the SBGM members.

Four essential competencies were defined aimed at allowing medical graduates to conjecture a diagnosis of a geneti- cally based condition; explain and propose to the patient the need to perform investigation to expand, confirm or rule out diagnostic hypotheses; and recommend genetic counselling. The four competencies specified were: (1) to recognise the necessity for continuing education, regularly examining one's own clinical competency, identifying learning gaps and the advances of genetics and of genomics over time; (2) to identify individuals that present or can develop a genetic disorder and know how and when to refer the patient to a specialist in medical genetics; (3) to manage patients with previously diagnosed genetic disorders and/or birth defects, employing established clinical guidelines in the scope of their professional role; and (4) to promote and stimulate clinical and education practices aimed at preventing genetic disorders/birth defects.

To devise the four competencies described above, a set of pieces of knowledge, skills and attitudes was outlined (Table 1), which form the basis of the proposed competency profile in genetics.

\section{FINAL CONSIDERATIONS}

A competency-based theoretical reference has been presented to support the teaching of genetics at Brazilian medical schools with the goal of training physicians who are more prepared to meet the current demands of the SUS. Devising a competency profile elucidates the recognition that physicians need essential minimum knowledge related to medical genetics, but also need certain indispensable skills and attitudes so that advances in genetics is adequately transferred into health care. That same competency profile can support permanent professional training actions in the area of genetics, so as to train SUS staff in relation to genetic disorders and birth defects.

The importance of physicians who are not specialists in genetics, especially those who work in PHC, is reinforced, especially in their recognition of patients and families who would benefit from specialist services and genetic counselling. In virtue of this conclusion, the proposal for this minimum competency profile in genetics being adopted in all Brazilian medical schools is defended.

\section{ACKNOWLEDGMENTS}

To Dr. Carolina Fischinger Moura de Souza and Dr. Temis Maria Felix, presidents of the Brazilian Society of Medical Genetics and Genomics (SBGM) for the periods of 2016-2018 and 2018-2020, respectively, for their support in the development of this work. To Dr. Angelina Xavier Acosta, coordinator of the Education Department of the SBGM at the time of conducting this study. 
TABLE 1

Knowledge, skills and attitudes necessary to attain the competency profile

in genetics proposed by the SBGM for physicians in Brazil

Recognise the importance of genetic disorders/birth defects in the local and national epidemiological context

Know the terminology and basic concepts used in medical genetics.

Know the classic patterns of inheritance within families and communities.

Recognise the importance of the genogram in assessing predisposition/susceptibility and the transmission of genetic disorders.

Have basic notions of morphogenesis and human physiology and of the role of genetics in these processes.

Know the basic principles of genetics and molecular biology (cellular division, chromosomal alterations, types of mutation, genetic code, etc.) and how they are associated to the formation of disorders, including aspects of carcinogenesis and neurogenetic disturbances.

Understand how the interaction of genetic, environmental and behavioural factors acts on the susceptibility at the onset and in the development of disorders, as well as on the maintenance of health and response to treatment.

Know the foundations of pharmacogenetics.

Recognise the main teratogenic agents and related preventive measures (especially alcohol and illegal drugs).

Recognise the main genetic risk factors - advanced parental age, consanguinity, family recurrence.

$\stackrel{5}{S}$ Know the preventive measures related to genetic disorders/birth defects - pre-conceptional folic acid, maternal immunizations, healthy living habits.

Recognise that genetic disorders are frequently multisystemic disturbances, requiring an interdisciplinary and multi-professional approach.

Know the principles and directives of the National Neonatal Triage Program.

Know the official and compulsory forms for registering genetic disorders/birth defects - Statement of Live Birth and Death Certificate. Know genetic disorders/birth defects that are not rare, that is, that have a prevalence of more than 1.3 in every 2,000 individuals.

Know the main genetic tests used in clinical practice.

Know the bases of genetic counselling.

Know the health care network available at the three levels of complexity for individuals with genetic disorders/birth defect and their families.

Know the attributes of the genetic physician in his recognition and management of genetic/congenital disorders, with the purpose of engaging the referral/counter-referral system.

Know the principles of genetics and basic molecular biology associated to the oncological mechanisms and the consequent interface between genetics and oncology (oncogenetics).

Know the principles of basic genetics and their interface with neurological disturbances (neurogenetics).

Gather information and interpret the genetic history of a family, including the construction of a genogram of at least three generations and recognition of inheritance patterns.

Recognise the variation of the normal phenotype and its morphological and functional alterations.

Adequately complete referral and counter-referral documents for patients with suspected or diagnosed genetic disorders and birth defects.

Use adequate communication skills and demonstrate awareness of the need for confidentiality and a non-directive approach to patients and their families.

Adequately use the technology available to obtain up-to-date information about genetics and genomics.

Recognise the main interfaces of genetics in different clinical fields in a multidisciplinary manner.

Respect non-directive and non-coercive genetic counselling.

Consider the patient's cultural and religious beliefs with respect to his genetic inheritance when caring for people with or at risk of developing genetic disorders.

Perceive the importance and need for privacy and confidentiality.

Be aware of the social and psychological impact of a genetic diagnosis on the patient and their family.

Work in a cooperative and collaborative manner in a cross-functional and multi-professional health team. 


\section{REFERENCES}

1. Jorde LB, Carey JC, Bamshad MJ, White RL. Conceitos e história: o impacto clínico das doenças genéticas. In: Genética Médica. 5 ed. Rio de Janeiro: Elsevier; 2017, p.1-5.

2. Passos-Bueno MR, Bertola D, Horovitz DD, Ferraz VEF, Brito LA. Genetics and genomics in Brazil: a promising future. Mol Genet Genomic Med. 2014; 2(4): 280-91.

3. Novoa MC, Burnham TF. Desafios para a universalização da genética clínica: o caso brasileiro. Rev Panam Salud Publica. 2011; 29(1): 61-8.

4. Melo DG, Germano CMR, Porciúncula CG, Paiva IS, Neri JICF, de Avó LRS, et al. Reflexões sobre a qualificação e o provimento de médicos no contexto da Política Nacional de Atenção Integral às Pessoas com Doenças Raras no SUS. Interface. 2017; 21(suppl.1): 11205-16.

5. Brasil. Câmara de Educação Superior. Portaria n ${ }^{\circ}$ 3, de 20 de junho de 2014. Institui as Diretrizes Curriculares Nacionais do Curso de Graduação em Medicina e dá outras providências. Diário Oficial da União da República Federativa do Brasil, Brasília, 23 de junho de 2014. [Accessed on: 2005-19]. Available at: http://pesquisa.in.gov.br/imprensa/ jsp /visualiza $/$ index.jsp?data=23/06/2014\&jornal=1\&pag ina $=8 \&$ totalArquivos $=64$

6. Turnpenny P, Ellard S. Emery's Elements of Medical Genetics. 15th ed. Amsterdam: Elsevier. 2017; 416 p.

7. Marques-de-Faria AP, Ferraz VE, Acosta AX, Brunoni D. Clinical genetics in developing countries: the case of Brazil. Community Genet. 2004; 7(2-3): 95-105.

8. Horovitz DDG, Llerena Jr. JC, Mattos RA. Atenção aos defeitos congênitos no Brasil: panorama atual. Cad SaúdePública. 2005; 21(4): 1055-64.

9. Christianson A, Howson CP, Modell B. March of Dimes Global Report on Birth Defects. New York: March of Dimes Birth Defects Foundation; 2006. [Accessed on: 20-05-19]. Available at: http://www.marchofdimes.com/downloads/Birth_Defects_Report-PF.pdf

10. Horovitz DD, Ferraz VEF, Dain S, Marques-de-Faria AP. Genetic services and testing in Brazil. J Community Genet. 2013; 4(3): 355-75.

11. Giugliani R. A Importância da Genética Médica e do Estudo de Defeitos Congênitos. In: Leite JCLL, Comunello LN, Giugliani, R, eds. Tópicos em Defeitos Congênitos. Porto Alegre: Editora da Universidade Federal do Rio Grande do Sul; 2002: p. 11-14.

12. Baumbusch J, Mayer S, Sloan-Yip I. Alone in a Crowd? Parents of Children with Rare Diseases' Experiences of Navigating the Healthcare System. J Genet Couns. 2018 [Epub ahead of print].
13. March of Dimes Birth Defects Foundation and World Health Organization. Management of birth defects and haemoglobin disorders: report of a joint WHO-March of Dimes Meeting. Geneva: WHO Press; 2006, 31 p. [Accessed on: 20-05-19]. Available at: http://www.who.int/genomics / publications/WHO-MODreport-final.pdf

14. Brasil. DATASUS -Departamento de Informação e Informática do SUS. Sistema de Informações de Saúde. Estatísticas Vitais - Mortalidade e Nascidos Vivos. 1996-2013. [Site na Internet] [Accessed on: 20-05-19]. Available at: http:/ / www.datasus.gov.br.

15. Brunoni D. Aconselhamento Genético. Ciênc Saúde Coletiva. 2002; 7(1): 101-7.

16. Scheffer M, Biancarelli A, Cassenote A. Demografia Médica no Brasil 2015. São Paulo: Departamento de Medicina Preventiva da Faculdade de Medicina da USP; Conselho Regional de Medicina do Estado de São Paulo; Conselho Federal de Medicina; 2015, 284 p. [Accessed on: 20-0519]. Available at: http://www.usp.br/agen/wp-content/ uploads/DemografiaMedica30nov20153.pdf

17. Acosta AX, Abé-Sandes K, Giugliani R, Bittles AH. Delivering genetic education and genetic counseling for rare diseases in rural Brazil. J GenetCouns. 2013; 22(6): 830-4.

18. Melo DG, Paula PK, Rodrigues SA, Avó LRS, Germano CMR, Demarzo MMP. Genetics in primary healthcare and the National Policy on Comprehensive Care for People with Rare Diseases in Brazil: opportunities and challenges for professional education. Journal of Community Genetics. 2015; 6(3):231-40.

19. Gramasco HFF, Baptista FH, Ribeiro MG, de Avó LRS, Germano CMR, Melo DG. Genetics in Primary Healthcare in Brazil: potential contribution of mid-level providers and community health workers. J Community Med Health 6(2): doi:10.4172/2161-0711.1000406

20. Brasil. Ministério da Saúde. Portaria GM/no 822, de 6 de junho de 2001. Cria o Programa Nacional de Triagem Neonatal (PNTN). Diário Oficial da União da República Federativa do Brasil, Brasília, 06 de junho de 2001. [Accessed on: 20-05-19]. Available at: http:/ / www.saude.mg.gov.br/ images/documentos/PORTARIA_822.pdf

21. Assembleia Legislativa do Estado de São Paulo. Lei №3.914, de 14 de novembro de 1983. Dispõe sobre diagnóstico precoce da Fenilcetonúria e do Hipotireoidismo Congênito nos hospitais e maternidades do Estado de São Paulo. [Accessed on: 20-05-19]. Available at: https:/ / www.al.sp.gov.br/repositorio/legislacao/lei/1983/lei-3914-14.11.1983.html

22. Assembleia Legislativa do Estado do Paraná. Lei 8627, de 09 de dezembro de 1987. Dispõe sobre a obrigatoriedade 
dos diagnósticos que especifica, nas crianças nascidas nas maternidades e casas hospitalares mantidas pelo Estado do Paraná. [Accessed on: 20-05-19]. Available at: https:/ / www.legislacao.pr.gov.br/legislacao/pesquisarAto.do?ac tion $=$ exibir\&codAto $=7031 \&$ codItemAto $=58705$

23. Ramalho AS, Magna LA, de Paiva-e-Silva RB. A Portaria MS n. $.022 / 01$ e a triagem neonatal das hemoglobinopatias CadSaude Publica. 2003; 19(4): 1195-9.

24. Leão LL, Aguiar MJ. Triagem neonatal: o que os pediatras deveriam saber. J Pediatr (Rio J). 2008; 84(4 Suppl): S80-90.

25. Botler J, Camacho LA, da Cruz MM, George P. Triagem neonatal - o desafio de uma cobertura universal e efetiva. CienSaude Colet. 2010; 15(2): 493-508.

26. Brasil, Ministério da Saúde. Programa Nacional de Triagem Neonatal [Site na Internet]. [Accessed on: 20-05-19]. Available at: http://portalms.saude.gov.br/acoes-e-programas/programa-nacional-da-triagem-neonatal

27. Brasil. Ministério da Saúde. Gabinete do Ministro. Portaria n. ${ }^{\circ} 1.060$ de 05 de Junho de 2002. Política Nacional de Saúde da Pessoa Portadora de Deficiência. Diário Oficial da União da República Federativa do Brasil, Brasília, 05 de junho de 2002. [Accessed on: 20-05-19]. Available at: http:/ / dtr2004.saude.gov.br/susdeaz/legislacao/arquivo/Portaria_1060_de_05_06_2002.pdf

28. Brasil. Ministério da Saúde. Secretaria de Atenção à Saúde. Política Nacional de Saúde da Pessoa Portadora de Deficiência / Ministério da Saúde, Secretaria de Atenção à Saúde - Brasília: Editora do Ministério da Saúde, 2008, 72 p. [Accessed on: 23-10-18]. Available at:http:/ / bvsms.saude.gov. br/bvs/publicacoes/politica_nacional_saude_pessoa_deficiencia.pdf

29. Brasil. Ministério da Saúde. Secretaria de Atenção à Saúde. Departamento de Ações Programáticas Estratégicas. Política Nacional de Saúde da Pessoa com Deficiência / Ministério da Saúde, Secretaria de Atenção à Saúde, Departamento de Ações Programáticas Estratégicas. - Brasília: Editora do Ministério da Saúde, 2010. 24 p. [Accessed on: 20-05-19]. Available at: http://bvsms.saude.gov.br/bvs/publicacoes/politica_nacional_pessoa_com_deficiencia.pdf

30. Brasil. Ministério da Saúde. Portaria nº. 793, de 24 de abril de 2012. Institui a Rede de Cuidados à Pessoa com Deficiência no âmbito do Sistema Único de Saúde. 2012. [Accessed on: 20-05-19]. Available at: http://bvsms.saude.gov. br/bvs/saudelegis/gm/2012/prt0793_24_04_2012.html

31. Machado WCA, Pereira JS, Schoeller SD, Júlio LC, Martins MMFPS, Figueiredo NMA. Integralidade na rede de cuidados da pessoa com deficiência. Texto contexto - enferm. 2018; 27(3): e4480016.
32. Brasil. Ministério da Saúde. Portaria $n^{\circ}$ 2.305, de 19 de dezembro de 2001. Aprova o Protocolo de Indicação de Tratamento Clínico da osteogenesisimperfecta com pamidronatodissódico no âmbito do Sistema Único de Saúde. Brasília, DF, 2001.

33. Brasil. Ministério da Saúde. Secretaria de Assistência à Saúde. Portaria no 263, de 18 de julho de 2001. Aprova o protocolo clínico e diretrizes terapêuticas - Fibrose cística - Enzimas pancreáticas. Brasília, DF, 2001.

34. Brasil. Ministério da Saúde. Secretaria de Assistência à Saúde. Portaria $n^{\circ} 449$, de 8 de julho de 2002. Aprova o protocolo clínico e diretrizes terapêuticas - Doença de Gaucher - Imiglucerase. Diário Oficial da União da República Federativa do Brasil, Brasília, 09 de julho de 2002.

35. Brasil. Ministério da Saúde. Secretaria de Assistência à Saúde. Portaria $n^{\circ} 847$, de 6 de novembro de 2002. Aprova o protocolo clínico e diretrizes terapêuticas - Fenilcetonúria - Fórmula de aminoácidos isenta de fenilalanina. Brasília, DF, 2002.

36. Brasil. Ministério da Saúde. Secretaria de Assistência à Saúde. Portaria $n^{\circ} 872$, de 12 de novembro de 2002. Aprova o protocolo clínico e diretrizes terapêuticas - Doença falciforme - Hidroxiuréia. Brasília, DF, 2002.

37. Brasil. Ministério da Saúde. Secretaria de Atenção à Saúde. Departamento de Ações Programáticas Estratégicas. Diretrizes de atenção à pessoa com Síndrome de Down. Brasília: Ministério da Saúde, 2013. 60 p. [Accessed on: 20-05-19]. Available at: http://bvsms.saude.gov.br/bvs/ publicacoes/diretrizes_atencao_pessoa_sindrome_down. pdf

38. Brasil. Agência Nacional de Vigilância Sanitária. Resolução RDC no 344, de 13 de dezembro de 2002. Aprova o regulamento técnico para a fortificação das farinhas de trigo e das farinhas de milho com ferro e ácido fólico. Diário Oficial da União da República Federativa do Brasil, Brasília, 18 de dezembro de 2002. [Accessed on: 20-05-19]. Available at: http:/ /189.28.128.100/dab/docs/portaldab / documentos/resolucao_rdc344_2002.pdf

39. Meira JGC, Acosta AX. Políticas de saúde pública aplicadas à Genética Médica no Brasil. Revista de Ciências médicas e biológicas. 2009; 8(2): 189-97.

40. Tomaz RVV, Rosa TL, Van DB, Melo DG. Public health policies for the intellectually disabled in Brazil: an integrative review. Cien Saúde Colet. 2016; 21(1): 155-72.

41. Nhoncanse GC, Melo DG. Confiabilidade da Declaração de Nascido Vivo como fonte de informação sobre os defeitos congênitos no Município de São Carlos, São Paulo, Brasil. CienSaude Colet. 2012; 17(4): 955-63. 
42. Cosme HW, Lima LS, Barbosa LG. Prevalência de anomalias congênitas e fatores associados em recém-nascidos do município de São Paulo no período de 2010 a 2014. Rev Paul Pediatr. 2017; 35(1): 33-8.

43. Brasil. Ministério da Saúde. Gabinete do Ministro. Portaria $\mathrm{n}^{\circ} 81$, de 20 de janeiro de 2009. Institui, no âmbito do SUS, a Política Nacional de Atenção Integral em Genética Clínica. Diário Oficial da União da República Federativa do Brasil, Brasília, 21 January 2009.

44. Brasil. Ministério da Saúde. Gabinete do Ministro. Portaria $\mathrm{n}^{\circ}$ 199, de 30 janeiro 2014. Institui a Política Nacional de Atenção Integral às Pessoas com Doenças Raras, aprova as Diretrizes para Atenção Integral às Pessoas com Doenças Raras no âmbito do Sistema Único de Saúde (SUS) e institui incentivos financeiros de custeio. Diário Oficial da União da República Federativa do Brasil, Brasília, 12 February 2014.

45. Melo DG, Gomes TLCS. Capacitação em Genética Médica para residentes em Medicina de Família e Comunidade: Relato de Experiência. Revista de APS. 2009; 12(1): 83-7.

46. Araújo D. Noção de competência e organização curricular. Rev. baiana saúde pública. 2007; 31(supl.1): 32-43.

47. Ramos MN. A pedagogia das competências: autonomia ou adaptação? São Paulo: Cortez, 2001, 320p.

48. Menezes ET, Santos TH. Verbete competência. Dicionário Interativo da Educação Brasileira - Educabrasil. São Paulo: Midiamix, 2001. [Accessed on: 20-05-19]. Available at: https://www.educabrasil.com.br/competencia

49. Marinho-Araujo C, Rabelo ML. Avaliação educacional: a abordagem por competências. Avaliação: Revista da Avaliação da Educação Superior (Campinas). 2015; 20(2): 443-66.

50. Irigoin M, Vargas F. Competencia laboral: manual de conceptos, métodos y aplicaciones en el sector salud. Montevideo: Cinterfor, 2002. 252p. [Accessed on: 20-05-19]. Available at: https: / / www.oitcinterfor.org/publicaci\%C3\%B3n/ competencia-laboral-manual-conceptos-m\%C3\%A9todos-aplicaciones-sector-salud

51. Perrenoud P, Thurler M, Macedo L, Machado N, Allessandrini $C$. As competências para ensinar no século XXI: a formação dos professores e o desafio da avaliação. Porto Alegre: Artmed Editora, 2002.

52. Fernandez N, Dory V, Ste-Marie LG, Chaput M, Charlin B, Boucher A. Varying conceptions of competence: an analysis of how health sciences educators define competence. Med Educ. 2012; 46(4): 357-65.

53. Sá P, Paixão F. Contributos para a clarificação do conceito de competência numa perspetiva integrada e sistémica. Rev. Port. de Educação. 2013; 26(1): 87-144.
54. Ramos MN. A educação profissional pela Pedagogia das Competências: para além da superfície dos documentos oficiais.Educ Soc. 2002; 23(80): 401-22.

55. Epstein MR, Hundert AM. Defining and Assessing Professional Competence. JAMA. 2002; 287(2): 226-87.

56. Santos WS, Organização curricular baseada em competência na educação médica. Revista Brasileira de Educação Médica. 2001; 35(1): 86-92.

57. Gontijo ED, Alvim C, Megale L, Melo JRC, Lima MECC. Matriz de competências essenciais para a formação e avaliação de desempenho de estudantes de medicina. Revista Brasileira de Educação Médica. 2013; 37(4): 526-39.

58. American Society of Human Genetics. Report from the ASHG Information and Education Committee: medical school core curriculum in genetics. Am J Hum Genet. 1995; 56(2): 535-37.

59. Friedman JM, Blitzer M, Elsas LJ 2nd, Francke U, Willard HF. Clinical objectives in medical genetics for undergraduate medical students. Association of Professors of Human Genetics, Clinical Objectives Task Force. Genet Med. 1998; 1(1): 54-5.

60. American Academy of Family Physicians. Core Educational Guidelines - Medical genetics: Recommended core educational guidelines for family practice residents. Am Fam Physician. 1999; 60(1): 305-7.

61. Lea DH. Position statement: integrating genetics competencies into baccalaureate and advanced nursing education. Nurs Outlook. 2004; 50(4): 167-68.

62. Riegert-Johnson DL, Korf BR, Alford RL, Broder MI, Keats $\mathrm{BJ}$, Ormond KE, et al. Outline of a medical genetics curriculum for internal medicine residency training programs. Genet Med. 2004; 6(6): 543-47.

63. Collins FS. Shattuck lecture - Medical and Societal consequences of the human genome project. New England J Med.1999; 341(1): 28-37.

64. Greendale K, Pyeritz RE. Empowering primary care health professionals in medical genetics: how soon? How fast? How far? Am J Med Genet. 2001; 106(3): 223-32.

65. Thurston VC, Wales PS, Bell MA, Torbeck L, Brokaw JJ. The current status of medical genetics instruction in US and Canadian medical schools. Acad Med. 2007; 82(5): 441-5.

66. Genetic Alliance; The New York-Mid-Atlantic Consortium for Genetic and Newborn Screening Services. Understanding Genetics: A New York, Mid-Atlantic Guide for Patients and Health Professionals. Washington (DC): Genetic Alliance; 2009 Jul 8. APPENDIX Q, National Coalition for Health Professional Education in Genetics (NCHPEG): 
Principles of Genetics for Health Professionals. [Accessed on: 20-05-19]. Available at: https://www.ncbi.nlm.nih. gov/books/NBK115543/

67. European Society of Human Genetics. Core competences in genetics for health professionals in Europe. 2008. [Accessed on: 20-05-19]. Available at: https://www.eshg. org/139.0.html.

68. Emery J, Hayflick S. The challenge of integrating genetic medicine into primary care. BMJ. 2001; 322(7293): 1027-30.

69. Scott J, Trotter T. Primary care and genetics and genomics. Pediatrics. 2013; 132(Suppl 3): S231-7.

70. Teng K, Acheson LS. Genomics in primary care practice. Prim Care. 2014; 41(2): 421-35.

71. Carroll JC, Rideout AL, Wilson BJ, Allanson JM, Blaine SM, Esplen MJ, et al. Genetic education for primary care providers: improving attitudes, knowledge, and confidence. Can Fam Physician. 2009; 55(12): e92-9.

72. Wilson BJ, Islam R, Francis JJ, Grimshaw JM, Permaul JA, Allanson JE, et al. Supporting genetics in primary care: investigating how theory can inform professional education. Eur J Hum Genet. 2016; 24(11): 1541-46.

73. Plunkett-Rondeau J, Hyland K, Dasgupta S. Training future physicians in the era of genomic medicine: trends in undergraduate medical genetics education. Genet Med. 2015; 17(11): 927-34.

74. Bijanzadeh M. Medical genetics teaching in Iranian medical schools, especially Ahvaz, south of Iran. J Adv Med Educ Prof. 2014; 2(2): 58-62.

75. Wolyniak MJ, Bemis LT, Prunuske AJ. Improving medical students' knowledge of genetic disease: a review of current and emerging pedagogical practices. Adv Med Educ Pract. 2015; 6: 597-607.
76. Dhar SU, Alford RL, Nelson EA, Potocki L. Enhancing exposure to genetics and genomics through an innovative medical school curriculum. Genet Med. 2012; 14(1): 163-7.

77. Hyland K, Dasgupta S. Medical genetics and genomics education and its impact on genomic literacy of the clinical workforce. Genet Med. 2019; 21(5):1259-60.

78. Porciúncula CGG. Avaliação do ensino de genética médica nos cursos de medicina do Brasil [tese]. Campinas, SP: Universidade de Campinas, 2004.

79. Melo DG, Demarzo MMP, Huber J. Ambulatório de genética médica na Apae: experiência no ensino médico de graduação. RevistaBrasileira de EducaçãoMédica. 2008; 32(3), 396-402.

\section{CONTRIBUTION OF THE AUTHORS}

Victor Evangelista de Faria Ferraz, Débora Gusmão Melo, André Anjos da Silva, Antonette Souto El Husny worked on the data analysis and interpretation and the final revision of the paper. Victor Evangelista de Faria Ferraz and Débora Gusmão Melo worked on the draft composition of the paper.

\section{CONFLICT OF INTEREST}

The authors declared no conflicts of interest.

\section{CORRESPONDENCE ADDRESS}

Victor Evangelista de Faria Ferraz

Faculdade de Medicina de Ribeirão Preto - USP

Departamento de Genética

Av. Bandeirantes, 3900

Vila Monte Alegre - Ribeirão Preto

CEP 14049-900 - SP

E-mail: victor.ferraz@gmail.com,vferraz@usp.br 